\title{
Industrial characteristics of sugarcane varieties under semi-arid conditions and different irrigation depths
}

\author{
Polliana Basilia Santana1, Ignacio Aspiazu1, Daniel Teixeira Pinheiro ${ }^{2 *}$, Matheus Ferreira França Teixeira ${ }^{2}$, \\ Hamilton Carvalho dos Santos Junior ${ }^{2}$, Édio Luiz da Costa ${ }^{3}$, Marcos Koiti Kondo ${ }^{1}$ \\ ${ }^{1}$ Departamento de Produç o Vegetal, Universidade Estadual de Montes Claros, Av. Reinaldo Viana, Bico da Pedra, Jana ba, MG, Brazil, \\ ${ }^{2}$ Departamento de Fitotecnia, Universidade Federal de Viçosa, Av. PH. Rolfs s n, Viçosa, MG, Brazil, ${ }^{3}$ Departamento de Produç o Vegetal, \\ Universidade Federal de So Jo o Del Rei, Rod., Sete Lagoas, MG, Brazil
}

\section{A B S T R A C T}

\begin{abstract}
Sugarcane quality for industry directly depends on irrigation, especially in semi-arid regions. This study aimed to evaluate the technological performance for industry of six sugarcane varieties at five irrigation depths. Sugar-cane Brix and Pol\%, juice Brix and Pol\%, fiber, purity, reducing sugars and total sugars were evaluated 11 months after planting. The experiment was conducted in Brazil, in the semi-arid region of Minas Gerais state. The experiment was arranged in a randomized block design, in a subdivided parcel scheme $(6 \times 5)$ and four repetitions. Different irrigation depths did not affected Brix. The cultivar RB83-5486 presented the highest value for juice Pol\%, among the evaluated varieties. Juice Pol\% and sugar-cane Pol\% presented similar behavior, and displayed the highest values at the $1081 \mathrm{~mm}$ irrigation depth. In general, the analyzed varieties presented low fiber content. All the analyzed varieties surpassed $80 \%$ purity. The highest irrigation depths enhanced purity. The highest value was obtained at the $1081 \mathrm{~mm}$ depth. Decreased reducing sugars and increased total reducing sugars were observed at the highest depths and the highest accumulation was found at the $1081 \mathrm{~mm}$ depth. As conclusion for industrial characteristics, the irrigation presented potential to enhance the technological performance of sugarcane in semi-arid conditions. Considering the technological performance for industry, the cultivar RB83-5486 has good potential to be used under the studied conditions. When higher levels of fiber and reduced sugars are desired, lower irrigation depths are recommended.
\end{abstract}

Keywords: Development; Industry; Production; Saccharum officinarum L.; water deficit

\section{INTRODUCTION}

Sugarcane (Saccharum officinarum L.) is one of the most important cultivated plants, with an average global sugar production of 188 million tons (USDA, 2018). Besides sugar, the main product derived from sugarcane is alcohol, which is exported and sold to fuel distributors, electricity companies and food industry. Some byproducts, such as vinasse, are used as fertilizers and sold to industries (PedroEscher et al., 2016; Parsaee et al., 2019).

Water deficit is one of the main factors that directly affect the development of sugarcane and consequently sugarcane technological quality (Lakshmanan and Robinson, 2014). Brazil is one of the 10 countries with the highest water availability, but many of its regions are considered semiarid, with extremely limited water resource (Montenegro and Ragab, 2012). According to Cardozo and Sentelhas
(2013), water restriction is the primary variable related to sugarcane ripening that directly affects production. In this context, irrigation is an indispensable practice for the achievement of adequate yield and technological quality, not only in Brazil, but also in all regions and countries with similar conditions (Walter et al., 2014).

Recent studies have reported the behavior of sugarcane under water deficit conditions. Boaretto et al. (2014) associated the improved performance of sugarcane under drought stress with a more efficient antioxidant system response, particularly under conditions of mild stress. Santana et al. (2017) observed that water deficit directly affected the agronomical performance of sugarcane in semi-arid conditions. Coelho et al. (2019) evaluated the higher heating value (HHV) and useful energy from biomass partitions of different sugarcane varieties drip irrigated at four water levels and four maturation

\footnotetext{
${ }^{*}$ Corresponding author:

Daniel Teixeira Pinheiro, Departamento de Fitotecnia, Universidade Federal de Viçosa Av. PH. Rolfs s.n 36570-000 Viçosa, MG, Brazil.

E-mail: pinheiroagroufv@gmail.com
}

Received: 02 July 2019; Accepted: 12 September 2019 
processes. Among other results, these authors concluded that the effect of water stress on the sugarcane "renewable energy produced" is totally dependent of the biomass quantity produced per unit of area.

The main goal of sugarcane agricultural industry is to maximize yield, reduce costs and associate raw material quality to the final products. In this context, sugarcane quality provided to the industry can be defined as a series of plant intrinsic characteristics, usually determined by technological analyses on samples collected on the supply moment and site (CONSECANA, 2006). According to Stupiello (1987), sugarcane quality depends on a set of attributes and should not be confused with the content of sucrose, which is its main component. Other important technological attributes of sugarcane which have been cited in the literature are $\mathrm{Pol} \%$, juice Pol\%, juice Brix, reducing sugars, apparent purity, fiber and others (Hossain et al., 2014; Li and Yang, 2015; Rhein et al., 2016).

However, few studies focus on varieties under water deficit, since in many semi-arid regions worldwide, it is still common to cultivate genetically degenerate sugarcane varieties, with low yield and inferior technological quality. Thus, it is desirable to introduce improved varieties, with high technological potential, aiming to increase sugarcane yield and quality in these regions.

Therefore, this study aimed to evaluate the technological quality for industry of different and technological through important attributes of sugarcane varieties, produced under different irrigation depths and semi-arid conditions.

\section{MATERIALS AND METHODS}

\section{Local, soil and plant material}

The experiment was conducted in the semi-arid region of Jaiba, Minas Gerais state, Brazil. The coordinates of the experimental area were $15^{\circ} 05^{\prime} 34^{\prime \prime}$ latitude and $43^{\circ} 58^{\prime}$ $44^{\prime \prime}$ W longitude, average temperature of $25.5^{\circ} \mathrm{C}$ (minimum of $18.7^{\circ} \mathrm{C}$ and maximum of $32.3^{\circ} \mathrm{C}$ ), annual insolation of 2987 hours, relative humidity of $65.5 \%$ and mean annual

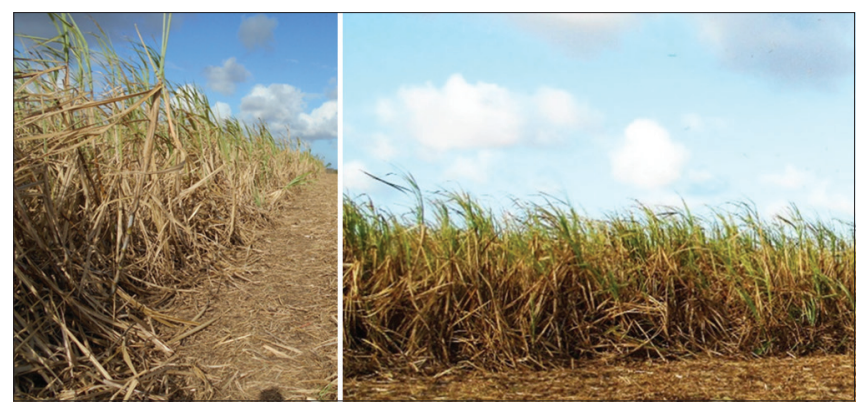

Fig 1. General perspective of the experiment 11 months after planting. rainfall is approximately $800 \mathrm{~mm}$, concentrated between October and March.

Previously to the experiment, soil samples were collected from the experimental area. The $0-20$ and $20-40 \mathrm{~cm}$ depths were used for the texture and fertility analysis. The soil was classified as dystrophic red latosol, with medium texture (Santos, 2013). Following the fertility test results, fertilization was performed according to Korndörfer et al. (1999), which consisted in the application of $150 \mathrm{~kg} \cdot \mathrm{ha}^{-1}$ of ammonium sulfate and $750 \mathrm{~kg} \cdot \mathrm{ha}^{-1}$ of single superphosphate before planting. Liming and micronutrient correction were not performed following the fertility analysis. Pre-planting fertilization was carried out in the trenches.

Before planting, the soil was prepared, aiming to reduce compaction, by subsoiling, plowing and two harrowing procedures. The six following sugarcane varieties were used, IAC86-2480, RB76-5418, RB83-5486, RB85-5536, SP80-1816 and SP80-1842. These varieties are potentially used in semi-arid regions of Brazil and are accessible to producers in these regions. The seedlings were distributed in trenches, 25 to $30 \mathrm{~cm}$ of depth, with $1.20 \mathrm{~m}$ spacing between them. Stalk selection criteria were 3 to 5 buds per stalk, resulting in 16 to 18 gems for each trench meter. The stalks were covered by a 5 to $10-\mathrm{cm}$ soil layer.

Cover fertilization consisted of $150 \mathrm{~kg} \cdot \mathrm{ha}{ }^{-1}$ of $\left(\mathrm{NH}_{4}\right)_{2} \mathrm{SO}_{4}$ and was performed 90 days after planting (DAP). During the crop cycle, the occurrence of pests and diseases was observed and controlled when necessary, through the chemical and biological procedures recommended for sugarcane crop (Dinardo-Miranda et al., 2007). Weed control was carried out trough chemical spraying, following the identification of weeds and the procedures recommended for sugarcane crops.

\section{Irrigation treatments}

Five irrigation depths were employed for all varieties. They consisted of 271, 541, 811, 1081 and $1351 \mathrm{~mm}$, which corresponded to $25,50,75,100$ and $125 \%$ of the recommended depth, respectively. Irrigation was performed by line Source sprinkling, with line of 11 nozzles, NAAN 5035 model, with evenly spaced distribution. Water was applied on decreasing levels and perpendicular to the tabulation. The height of the sprinklers was proportional to the plant growth and they were spaced $12 \mathrm{~m}$ away from each other (Fig. 2). Irrigation outflow was 3100 L.h ${ }^{-1}$.

Irrigation management was performed using potential reference evapotranspiration (ETo), calculated according to (Eq. 1). For this calculation, precipitation data were collected from a meteorological station near the experimental area. The results of this equation presented the irrigation period for each treatment. the irrigation 


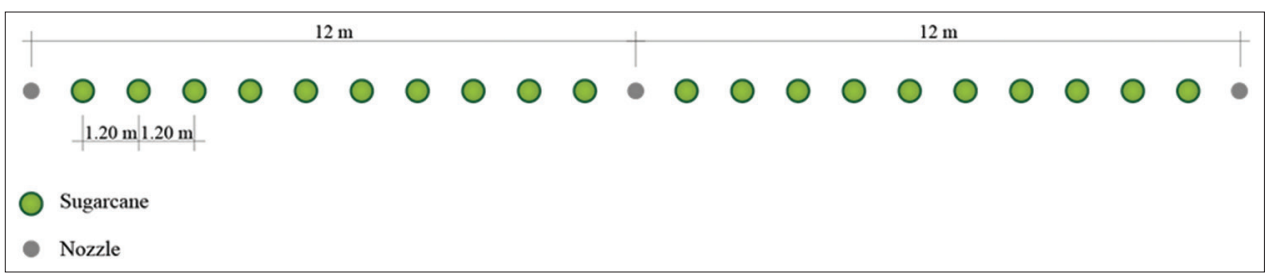

Fig 2. Irrigation system used in sugarcane cultivation.

periods ranged from 1 to 3 days, according to irrigation management (Bernardo et al., 2006).

$$
\text { Eto }=0.0023 \times \operatorname{Ra} \times(T+17.8) \times(\operatorname{Tmax}-T \min )^{0,5}
$$

Where: $\mathrm{ETo}=$ day mean evapotranspiration, $\mathrm{mm}^{\mathrm{d}} \mathrm{day}^{-1}$

$\mathrm{T}=$ day mean temperature $\left({ }^{\circ} \mathrm{C}\right)$,

Tmax $=$ day max temperature, $\left({ }^{\circ} \mathrm{C}\right)$,

Tmin $=$ day minimum temperature, $\left({ }^{\circ} \mathrm{C}\right)$ and

$\mathrm{Ra}=$ radiation at the top of the atmosphere $\left(\mathrm{mm}^{\mathrm{d} d a y^{-1}}\right)$.

An irrigation uniformity test was performed using collectors on the irrigation line, aiming to effectively quantify the water outflow. Irrigation was interrupted 45 days before harvest. Harvest and evaluations were performed when the plants were 11 months old.

\section{Technological analysis}

Three whole culms were collected from each parcel for technological analysis, following the manual of sugarcane quality analysis (CONSECANA, 2006). The collected culms were sectioned according to Fig. 3.:

\section{Brix and sugarcane juice Pol\%.}

Disintegration and homogenization were performed using a concrete mixer equipped with protection to prevent moisture decrease. Then, $500 \mathrm{~g}$ of sample were weighed on an electronic scale. These samples were pressed under $250 \mathrm{kgf.cm}{ }^{-2}$ for one minute, on a hydraulic press (Hidraseme PHS 250). The juice was collected from the press for Brix analysis (refractometer) (CONSECANA, 2006).

The juice Pol $\%$ is the percentage of sucrose mass contained in a sugary solution of normal weight, determined by the capacity of sugars to divert polarized light to a single direction. Pol is determined by saccharimetric methods (polarimeters or saccharometers) (CONSECANA, 2006). It was calculated by Eq. 2:

$$
\begin{aligned}
\text { JuicePol }= & (1.0078 \times \text { sucrose }+0.0444) \times(0.2607- \\
& 0.009882 \times \text { Brix })
\end{aligned}
$$

\section{Sugarcane fiber}

The fiber was determined by the juice Brix extracted from the hydraulic press, humid bagasse (HB) and dry bagasse (DB), following Fernandes (2003). The fiber was determined by Eq. 3:

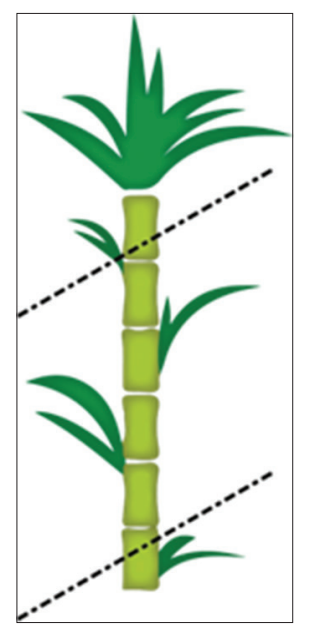

Fig 3. Section of sugarcane culms for technological analysis.

$$
\mathrm{F}=(0.08 \times \mathrm{HBW})+0.876
$$

Where: $\mathrm{F}=$ fiber percentage and

$\mathrm{HBW}=$ humid bagasse weight.

\section{Coefficient C}

The coefficient " $C$ " represents the transformation of the extracted juice into the whole juice. It is the extraction of all juice from the hydraulic press, determined by Eq. 4:

$$
C=(1.0313-0.00575 \times \text { Fiber })
$$

\section{Sugarcane ${ }^{\circ}$ Brix}

The refractometer Brix is determined by the measure of the refraction index of the dissolved solutions on a sugary solution, which provides the mass on percentage. Measuring was performed using an optical refratometer with $20{ }^{\circ} \mathrm{C}$ correction. Approximately $50 \mathrm{~mL}$ of juice, filtered through cotton, were used for the measurement. Droplets of the filtered juice were placed on the refratometer prism, followed by the Brix measurement. Eq. 5 was used to determine the sugarcane Brix:

$$
\text { Sugarcane }{ }^{\circ} \text { Brix }=\text { JuiceBrix x }(1-0.01) \times C
$$

\section{Sugarcane Pol\%}

Sugarcane Pol is obtained when juice Pol is multiplied by the fiber and coefficient " $\mathrm{C}$ ", which transforms the juice Pol into Sugarcane Pol\%, according to Eq. 6: 


$$
\text { Sugarcane Pol=Juice Pol x (1-0.01 x Fiber)x C }
$$

Where: $\mathrm{C}=$ Coefficient of juice transformation.

\section{Purity}

Purity is the percentage of sucrose (Pol) contained in the soluble solids (Brix). This is the main indicator of maturity. Eq. 7 was used to determine it:

$$
\text { Purity }=\frac{(\text { Sugarcane Pol })}{\left(\text { Sugarcane }^{\circ} \text { Brix }\right)} \times 100
$$

\section{Reducing sugars (RS\%)}

Glucose and fructose are the main reducing sugars present in sugarcane. These sugars have potential to reduce copper from cupric into cuprous. These are the main precursors of the sugar dark color in industrial processes (Tasso Júnior, 2009). Eqs. 8 and 9 were used to calculate the reducing sugars in juice and sugarcane, respectively:

$$
\text { Juice RS }=(3.641-0.0343 \times \text { Purity })
$$

Sugarcane RS=Juice RS x (1-0.01 x Fiber $)$ x C

Where: $\mathrm{C}=$ Coefficient of juice transformation.

\section{Total reducing sugars (TRS\%)}

The total reducing sugars, also known as total sugars, regard all sugars contained in sugarcane in a reducing form or inverted sugar (Oliveira et al., 2014). Eqs. 10 and 11 were used to calculate the total reducing sugars in juice and sugarcane, respectively:

$$
\text { Juice TRS } \%=\text { (Juice Pol }) /(0.95)+\text { Juice RS }
$$

Sugarcane TRS $\%=$ Juice TRS $\% \times(1-0.01 \times$ Fiber $) \times C$

Where: $\mathrm{C}=$ Coefficient of juice transformation.

\section{Total recoverable sugars (TReS\%)}

Using sugarcane Pol (PC) and sugarcane reducing sugars (SRS), the TReS is calculated by Eq. 12:

$\mathrm{TReS}=10 \times P S \times 1.05263 \times 0.905+10 \times S R S \times 0.905$

Where: $10 \times$ PS $=$ Pol per sugarcane ton,

$1.05263=$ stoichiometric coefficient to the conversion of sucrose in reducing sugars,

$0.905=$ Recovery coefficient to an industrial loss of 9.05 $\%$ and

$10 \times$ SRS $=$ Reducing sugars per sugarcane ton.

\section{Experimental design and statistical analysis}

The experiment was arranged in a randomized block design, in a subdivided parcel scheme $(6 \times 5)$. The six varieties were used in the parcels (IAC86-2480, RB76-5418, RB83-5486, RB85-5536, SP80-1816 and SP80-1842) and sub-parcels composed of five irrigation depths $(271,541$, 811,1081 and $1351 \mathrm{~mm}$ ), with four repetitions. The total area presented $5000 \mathrm{~m}^{2}(100 \times 50 \mathrm{~m})$.

The parcels were arranged parallel to the irrigation lines. Sub-parcels presented $33.75 \mathrm{~m}^{2}(7.5 \times 4.5 \mathrm{~m})$ and were composed of five $8 \mathrm{~m}$ lines. Externally to the parcels, three lines of sugarcane, RB73-9735 cultivar, were planted as turnrows (headlands).

The data were statistically analyzed on bulk and the means were compared to the rates of the varieties, by the Tukey test. Data unfolding was performed for significant interactions. Regression analysis was performed for significant interactions identified by the $\mathrm{F}$ test $(\mathrm{P}<0.05)$. The models used to explain the results were chosen considering the significance of the equation parameters and determination coefficient value $\left(R^{2} \geq 0.70\right)$.

\section{RESULTS AND DISCUSSION}

Regarding the variance analysis, it was observed that no interaction with other variation source was observed only for brix evaluation, which suggests that the different depths did not affect this characteristic of the studied varieties. For the varieties, was significant difference was detected for Juice Pol $\%$ and TRS at $1 \%$ probability. Regarding purity and $\mathrm{RS} \%$, the significance level was $5 \%$. For irrigation depth, significant differences were observed for all the characteristics at $1 \%$ probability. No significant difference was detected by the $\mathrm{F}$ test for ${ }^{\circ} \mathrm{Brix}$ and fiber. The cultivar $\mathrm{x}$ irrigation depth interaction presented significant effect at $5 \%$ probability only for the fiber variable.

\begin{tabular}{|c|c|}
\hline Varieties & Juice Pol\% \\
\hline IAC86-2480 & $15.72^{b}$ \\
\hline RB76-5418 & $14.90^{\mathrm{b}}$ \\
\hline RB83-5486 & $17.85^{a}$ \\
\hline RB85-5536 & $15.56^{b}$ \\
\hline SP80-1816 & $16.49^{a b}$ \\
\hline SP80-1842 & $16.20^{b}$ \\
\hline
\end{tabular}

The cultivar RB83-5486 presented the highest juice Pol\% value, $17.85 \%$. Significant differences were not observed between the varieties SP80-1816 and SP80-1842. The

(a) Means followed by the same letters in the column not differ based on Tukey test $(P=0.05)$. 
cultivar RB76-5418 presented the lowest value for this characteristic, $14.90 \%$ (Table 1).

The results suggest that the maturation behavior of cultivar RB83-5486 may indicate precocious harvest. This process can be related to a higher accumulation of sucrose within the studied varieties. Souza et al. (2005) observed similar results, with values higher than $15.3 \% \mathrm{Pol} \%$ (which indicates the first sugarcane cut), except for the variety RB76-5418 (Table 1).

Oliveira et al. (2014) studied the cultivars RB85-5453 and SP80-1816 under different irrigation and fertilization conditions and observed mean values of 17.59 for sugarcane $\mathrm{Pol} \%$ and 20.97 for juice $\mathrm{Pol} \%$, which exceed the mean values found in this study.

Regarding irrigation depths, for juice $\mathrm{Pol} \%$ and sugarcane $\mathrm{Pol} \%$, a similar behavior was observed. The highest values were found for the $1081 \mathrm{~mm}$ depth, with a tendency of decrease at $1351 \mathrm{~mm}$ (Fig. 4).

Similar results were observed by Dantas Neto et al. (2006). Increased Pol values were observed for higher irrigation depths up to a certain limit, followed by a decrease. Dalri and Cruz (2008) verified results similar to those and observed for sugarcane Pol\%, with values of $15.7 \%$. Silva et al. (2014) observed values of sugarcane Pol\% above

\begin{tabular}{|c|c|c|c|c|c|}
\hline \multirow[t]{2}{*}{ Varieties } & \multicolumn{4}{|c|}{ Irrigation depths (mm) } & \multirow[b]{2}{*}{1351} \\
\hline & 271 & 541 & 811 & 1081 & \\
\hline IAC86-2480 & $9.77^{a}$ & $9.09^{a}$ & $2.58^{b}$ & $2.31^{a}$ & $4.43^{a}$ \\
\hline RB76-5418 & $10.52^{\mathrm{a}}$ & $8.28^{\mathrm{a}}$ & $7.90^{\mathrm{ab}}$ & $10.69^{a}$ & $10.92^{\mathrm{a}}$ \\
\hline RB83-5486 & $12.59^{a}$ & $7.91^{\mathrm{a}}$ & $5.60^{\mathrm{ab}}$ & $9.84^{\mathrm{a}}$ & $8.84^{\mathrm{a}}$ \\
\hline RB85-5536 & $7.77^{\mathrm{a}}$ & $5.27^{\mathrm{a}}$ & $11.07^{\mathrm{ab}}$ & $6.85^{\mathrm{a}}$ & $9.73^{a}$ \\
\hline SP80-1816 & $5.99^{\mathrm{a}}$ & $9.07^{a}$ & $13.25^{\mathrm{a}}$ & $8.31^{a}$ & $7.52^{\mathrm{a}}$ \\
\hline SP80-1842 & $10.26^{a}$ & $10.55^{\mathrm{a}}$ & $8.30^{\mathrm{ab}}$ & $9.50^{\mathrm{a}}$ & $2.60^{\mathrm{a}}$ \\
\hline
\end{tabular}

(a) Means followed by the same letters in the column not differ based on Tukey test $(\mathrm{P}=0.05)$
14\% for the cultivars SP89-1115 and IACSP96-3060, under drip irrigation.

In general, the analyzed varieties presented low fiber potential. Significant differences among varieties were observed only for the $811 \mathrm{~mm}$ depth, where the varieties SP80-1816 and IAC86-1480 presented the highest (13.25\%) and lowest $(2.58 \%)$ values, respectively (Table 2$)$.

At the $811 \mathrm{~mm}$ depth, the variety SP80-1816 presented values higher than those recommend to mill processes, which are between 10 and 11\% (Fernandes, 2003). Bagasse is the material that remained after sugarcane stalks were crushed for the extraction of juice (Boomtima et al., 2015). Thus, high fiber content affects juice extraction.

The varieties IAC86-2480 and SP80-1842 presented a similar behavior for fiber. Decreased fiber content was observed for higher irrigation depths. However, the cultivar SP80-1816 presented the highest fiber content at the $811 \mathrm{~mm}$ depth, and the lowest values at the 271, 541, 1081 and $1351 \mathrm{~mm}$ depths (Fig. 5).

Similarly to the varieties IAC86-2480 and SP80-1842, according to Dias et al. (2012), the fiber content in nonirrigated areas is higher, compared to irrigated areas. Under water deficit conditions, sugarcane tends to accumulate fiber (Farias et al., 2009). Gonçalves et al. (2014) observed between 11 and $13 \%$ fiber contents in sugarcane. According these authors, lower levels of fiber predispose plants to lodging and difficulties in harvesting.

Carlin and Santos (2009) mention that higher sucrose content is related with lower fiber percentage, a hypothesis that can be observed in this study with the cultivar IAC86-2480 (Table 2 and Fig. 4). However, these authors affirm that variations in fiber content among different cultivars are genetic and differ according to the given conditions. In general, the varieties RB76-

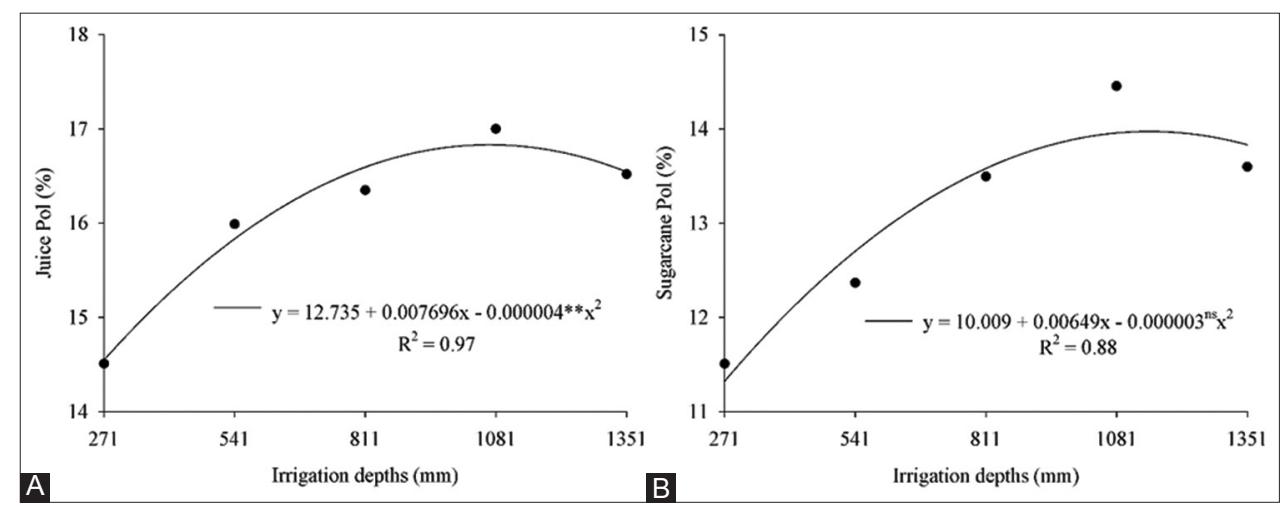

Fig 4. Juice Pol\% (A) and sugarcane Pol\% (B) for sugarcane under five different irrigation depths, 11 months after planting. ns, **: Equations are not significant and significant at $1 \%$ probability $(P<0.01)$, respectively. 


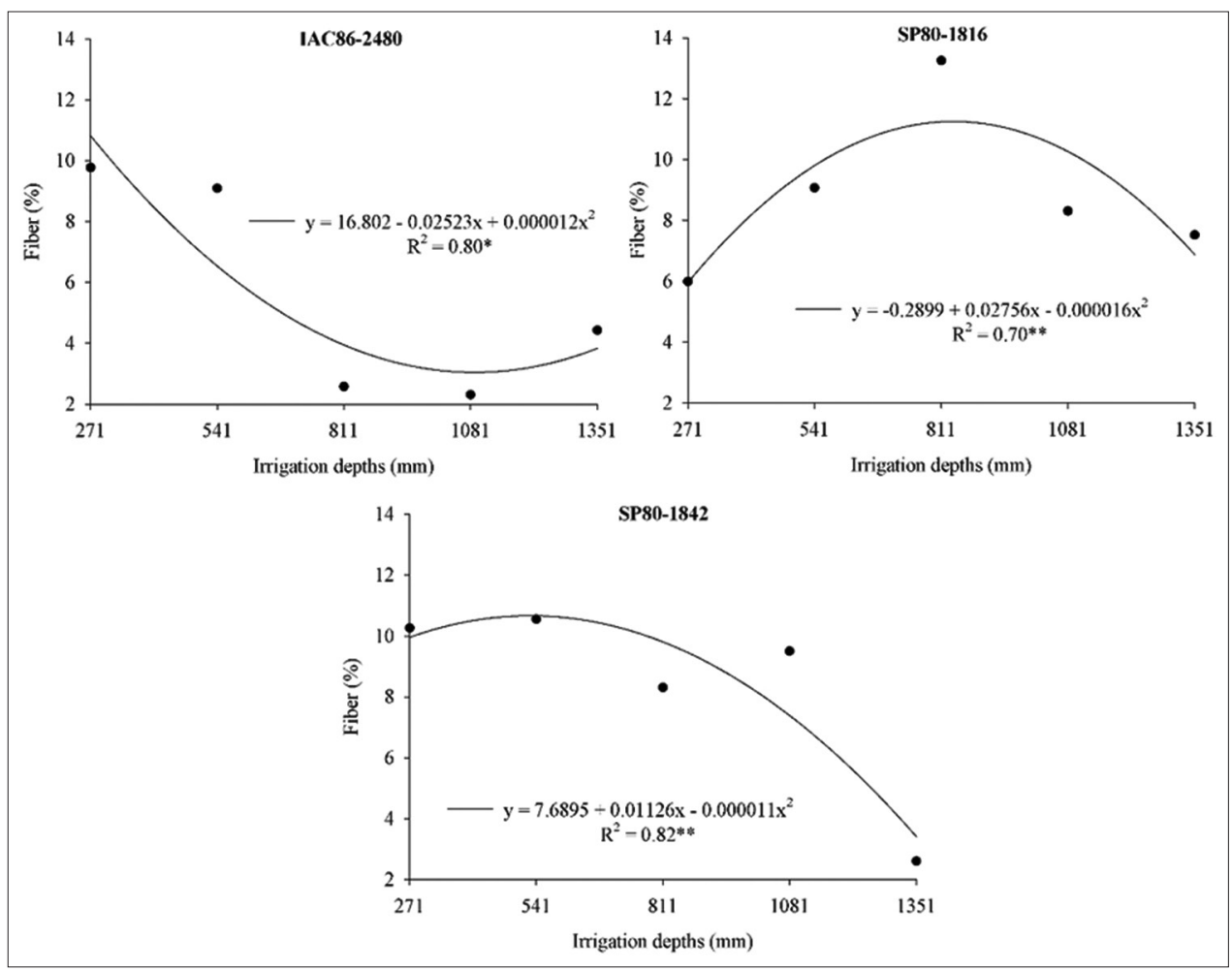

Fig 5. Sugarcane fiber content at five different irrigation depths, 11 months after planting. ${ }^{*},{ }^{* *}$ : Equations are significant by $\mathrm{F}$ test, at $5 \%(\mathrm{P} \leq 0.05)$ and $1 \%(P \leq 0.01)$ probability, respectively.

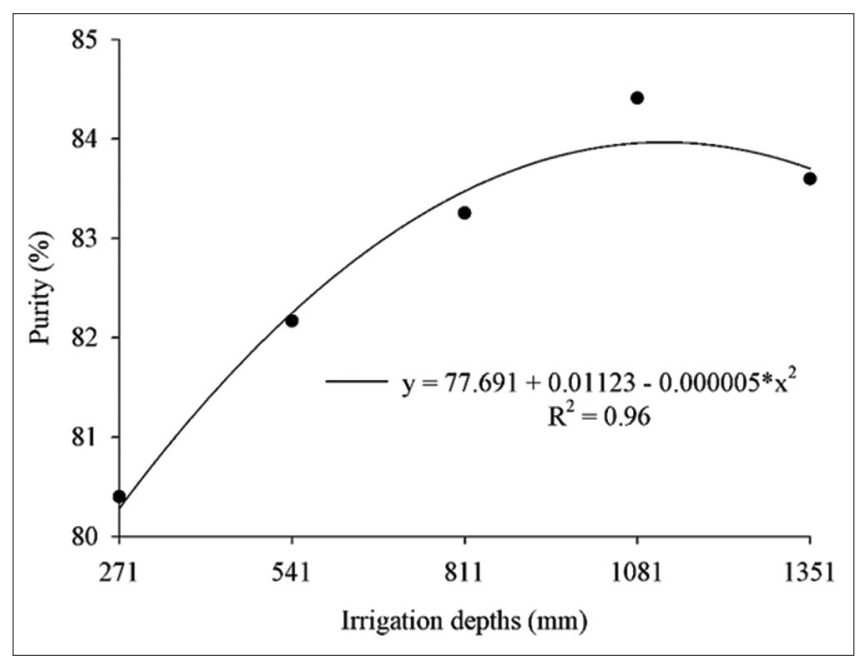

Fig 6. Purity of sugarcane at five different irrigation depths, 11 months after planting. *: Equation is significant by $\mathrm{F}$ test, at $5 \%(\mathrm{P} \leq 0.05)$.

5418, RB83-5486 and RB85-5536-5536 showed a similar behavior (reduction of fiber content with increasing irrigation depths), indicating low genetic variability between them for this parameter.

The variety RB83-5486 presented the highest purity $(87.13 \%)$ among the analyzed varieties. On the other hand, the varieties IAC86-2480 did not differ from RB765418, RB85-5536, SP80-1816 and SP80-1842.
Table 3: Purity of 6 sugarcane varieties, 11 months after planting

Varieties

Purity

IAC86-2480

RB76-5418

$81.30^{\mathrm{b}}$

RB83-5486

$87.13^{\mathrm{a}}$

RB85-5536

$82.55^{\mathrm{ab}}$

SP80-1816

$82.87^{\text {ab }}$

SP80-1842

$81.84^{b}$

(a) Means followed by the same letters in the column not differ based on Tukey test $(\mathrm{P}=0.05)$

The purity of sugarcane juice is directly related to the raw material quality and can be affected by the mineral and plant impurities incorporated during harvest. It is important to obtain values of purity above $80 \%$ during the harvest process. Industrial unities usually reject raw materials with purity lower than $75 \%$ (CONSECANA, 2006).

In this context, all the analyzed varieties presented over $80 \%$ purity, evidencing the good quality of the raw materials (Fernandes, 2003) (Table 3). Similar harvest results were observed by Prado and Pancelli (2006) and Silva et al. (2008), who obtained values of 84.4 and $83.8 \%$, respectively. Rhein et al. (2016) evaluated the purity of sugarcane cultivar SP80-3280 under nitrogen doses via drip irrigation and also observed increased purity. It was observed that higher irrigation depths 
increased purity, and the maximum value was obtained at $1081 \mathrm{~mm}$ (Fig. 6).

Farias et al. (2009) also observed that purity was affected by the irrigation depth, with an increase of $10 \%$ to the characteristic when compared to areas without irrigation. A high purity percentage provides a high sucrose concentration in the sugarcane juice, which results in higher industrial yield, propitiated by irrigation. Increased purity is also related to higher sugarcane juice quality, according to a reduction in amino acids, organic acids, starch, reducing sugars and color related substances (Silva et al., 2014).

The cultivars presented significant differences for reducing sugars (RS) and total reducing sugars (TRS). The varieties IAC86-2480, RB76-5418 and SP80-1842 presented the highest RS values and no significant differences. The

\begin{tabular}{|c|c|c|}
\hline Varieties & RS (\%) & TRS (\%) \\
\hline IAC86-2480 & $0.73^{a}$ & $14.43^{\mathrm{ab}}$ \\
\hline RB76-5418 & $0.71^{\mathrm{a}}$ & $12.86^{b}$ \\
\hline RB83-5486 & $0.55^{\mathrm{b}}$ & $16.45^{\mathrm{a}}$ \\
\hline RB85-5536 & $0.69^{\mathrm{ab}}$ & $14.63^{\mathrm{ab}}$ \\
\hline SP80-1816 & $0.66^{\mathrm{ab}}$ & $15.20^{\mathrm{a}}$ \\
\hline SP80-1842 & $0.70^{\mathrm{a}}$ & $15.09^{a}$ \\
\hline
\end{tabular}

(a) Means followed by the same letters in the column not differ based on Tukey test $(\mathrm{P}=0.05)$ varieties RB83-5486 presented the highest TRS value, similarly to the cultivars IAC86-2480, RB85-5536, SP801816 and SP80-1842 (Table 4).

These results corroborate those observed to juice Pol\% and purity. The variety RB83-5486 presented the best values among the analyzed varieties. The observed RS values $(<1 \%)$ are acceptable for sugar/alcohol production (Oliveira et al., 2014).

It was observed that increased irrigation depth reduced RS and increased TRS and TReS, with maximum accumulation at $1081 \mathrm{~mm}$ (Fig. 7).

Cardozo et al. (2015) studied the effects of water deficit on sugarcane ripening and observed a high correlation among water availability, Brix, Pol, TRS and purity. The TRS represents all sugarcane sugars, although other reducing substances present in sugarcane juice can also be included. The unfolding of sucrose into glucose and fructose is a two way reaction that occurs in the plant. Similarly, the reaction inversion occurs as the combined processes of photosynthesis metabolism and plant respiration (Fernandes, 2003).

Therefore, the reduced photosynthetic process can directly or indirectly affect sugar production, as observed by Silva et al. (2012) in sugarcane under

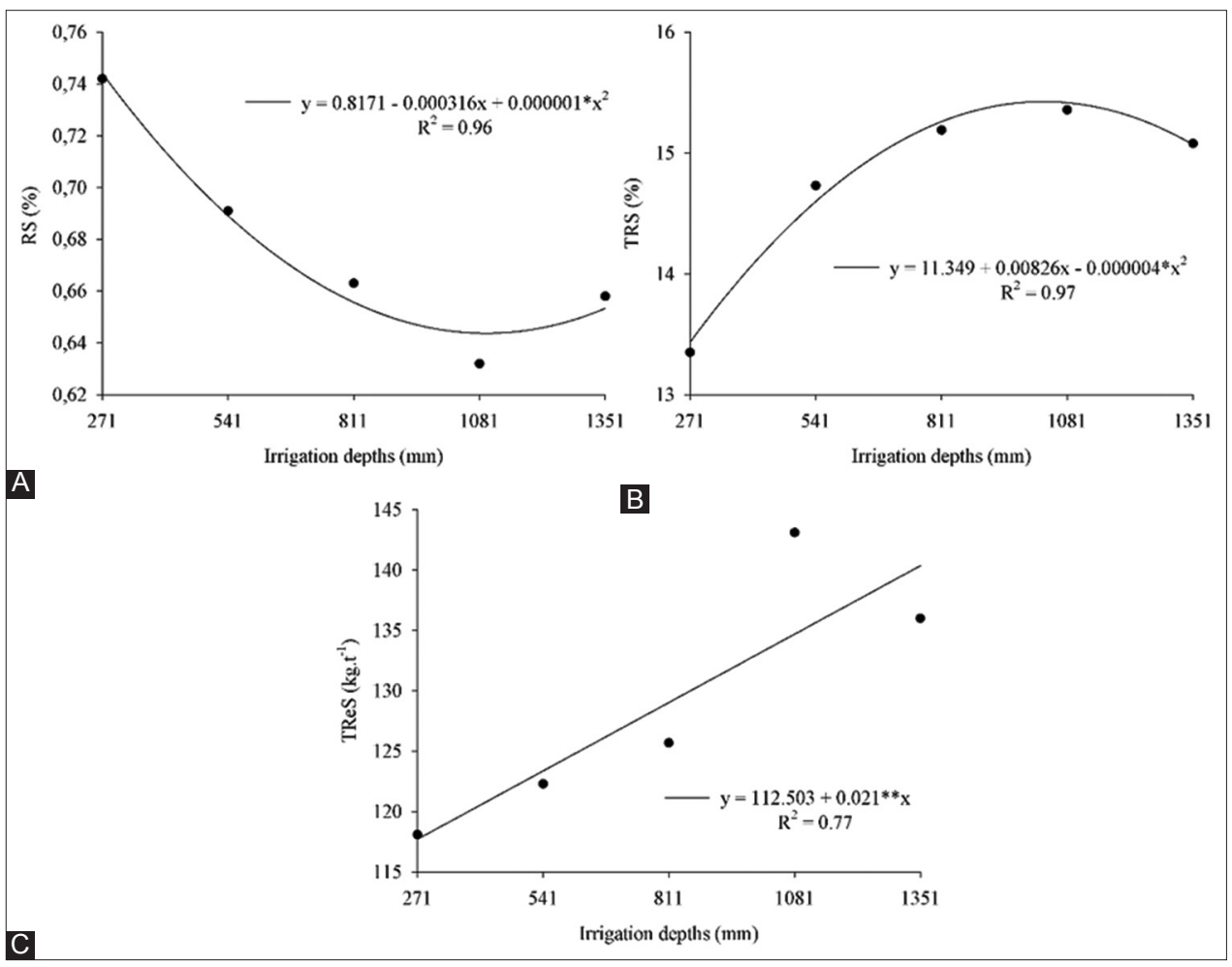

Fig 7. RS (A) TRS (B) and TReS (C) of sugarcane at five different irrigation depths, 11 months after planting. *,**: Equations are significant by $\mathrm{F}$ test, at $5 \%(\mathrm{P} \leq 0.05)$ and $1 \%(\mathrm{P} \leq 0.01)$ probability, respectively. 
drought stress. Zhao et al. (2013) observed when the sugarcane plants were submitted to increasing periods of water stress, chlorophyll level, stomatal conductance, net photosynthetic rate and transpiration rate rapidly declined. Júnior et al. (2019) investigated the physiological responses of sugarcane varieties under drought stress conditions and among the conclusions, they cited that leaf width, specific leaf area, stomatal conductance, transpiration, photosynthesis and carboxylation efficiency were quite sensitive to changes in soil humidity. The water stress tolerance may also be associated with a more efficient enzymatic antioxidant system. Boaretto et al. (2014) reported that the improved performance of sugarcane under drought stress was associated with a more efficient antioxidant system response, particularly under mild stress conditions.

The higher TReS value, regarding the studied treatments, occurred when the crop was irrigated at $1081 \mathrm{~mm}$ approximately $143 \mathrm{~kg} \cdot \mathrm{t}^{-1}$. At $1351 \mathrm{~mm}$, sugar production reached approximately $138 \mathrm{~kg} \mathrm{t}^{-1}$, which accounts for a difference of $5 \mathrm{~kg} \mathrm{t}-1$ when compared with the $1081 \mathrm{~mm}$ depth (Fig. 6C). These results corroborate the findings of Farias et al. (2009), in which the best TReS values where obtained at the $100 \%$ depth $(1026.57 \mathrm{~mm})$.

In general, the beneficial effects of irrigation on technological quality can be related to increased root development and the establishment of tillers (Surendran et al., 2016). These factors enhance the capitation of low mobility ions, such as phosphorus $(\mathrm{P})$ and increase nutrient cycling and plant tolerance to a wide range of stresses (Surendran and Murugappan, 2010). Water stress may reduce the amount of roots in the soil surface and affect sugarcane production and quality, as observed by Otto et al. (2009). However, Neto et al. (2018) reports that the production and distribution of sugarcane from the biomass of the roots did not explain sugarcane yield. It is important to emphasize that other factors such as light (quality and intensity) can affect vegetative development and maturation, since they directly affect synthesis, accumulation and translocation of carbohydrates from the leaves to the culm.

However, it must be pointed out that, besides enhancing technological quality, irrigation also works in a combined form, especially with cultivars adapted to the edaphic local conditions, which favors quality enhancement (Carvalho et al., 2009). In this context, Uribe et al. (2013) compared the use of water and nitrogen during irrigated and rain-fed conditions in different cultivars of sugarcane and observed a synergic effect of the combined application of these factors. Lastly, technological performance should be aligned with satisfactory yield.

\section{CONCLUSIONS}

For industrial characteristics, the irrigation presented potential to enhance the technological performance of sugarcane varieties in semi-arid conditions. Although all the varieties have potential for these conditions, RB83-5486 has good potential to be used under the studied conditions, with superior results for JuicePol\%, purity and total reducing sugars. In this way, if this variety reaches a satisfactory yield, can be indicated for semi-arid conditions. When higher levels of fiber and reducing sugars are desired, lower irrigation depths are recommended, especially $271 \mathrm{~mm}$.

\section{ACKNOWLEDGMENTS}

The authors are thankful to the Universidade Estadual de Montes Claros and Programa de Pós-Graduação em Produção Vegetal no Semiárido (Graduate Program in Plant Production in the Semi-arid Region), for the opportunity to develop the present study, to the Empresa de Pesquisa Agropecuária de Minas Gerais (EPAMIG), Fundação de Amparo à Pesquisa do Estado de Minas Gerais (FAPEMIG) and Usina São Judas Tadeu (SADA Bioenergia) for the financial support.

\section{Authors' contributions}

Author Polliana Basilia Santana designed the study, performed the statistical analysis, wrote the protocol and wrote the first draft of the manuscript. Authors Ignacio Aspiazu, Édio Luiz da Costa and Marcos Koiti Kondo were advisor and co-advisors, respectively, helping on all steps. Authors Daniel Teixeira Pinheiro, Matheus Ferreira França Teixeira and Hamilton Carvalho dos Santos Junior managed the literature review, worked translating Portuguese to English and sent to English review by a native speaker. This work was carried out in collaboration between all authors. All authors read and approved the final manuscript.

\section{REFERENCES}

Bernardo, S., A. A. Soares and E. C. Mantovani. 2006. Manual de Irrigação. UFV, Viçosa.

Boaretto, L. F., G. Carvalho, L. Borgo, S. Creste, M. G. Landell, P. Mazzafera and R. A. Azevedo. 2014. Water stress reveals differential antioxidant responses of tolerant and non-tolerant sugarcane genotypes. Plant Physiol. Biochem. 74: 165-175.

Boontima, B., A. Noomhorm, C. Puttanlek, D. Uttapap and V. Rungsardthong. 2015. Mechanical properties of sugarcane bagasse fiber-reinforced soy based biocomposites. J. Polym. Environ. 23: 97-106.

Cardozo, N. P. and P. C. Sentelhas. 2013. Climatic effects on sugarcane ripening under the influence of cultivars and crop age. Sci. Agric. 70: 449-456. 
Cardozo, N. P., P. C. Sentelhas, A. R. Panosso, A. L. Palhares and B. Y. Ide. 2015. Modeling sugarcane ripening as a function of accumulated rainfall in Southern Brazil. Int. J. Biometeorol. 59: 1913-1925.

Carlin, S. D. and D. M. M. Santos. 2009. Indicadores fisiológicos da interação entre déficit hídrico e acidez do solo em cana-deaçúcar. Pesq. Agropec. Bras. 44: 1106-1113.

Carvalho, C. M. D., H. M. D. Azevedo, J. Dantas-Neto, C. H. D. Farias, C. H. D. Silva and R. R. G. Filho. 2009. Rendimento de açúcar e álcool da cana-de-açúcar submetida a diferentes níveis de irrigação. Rev. Bras. Ciênc. Agrárias. 4: 72-77.

Coelho, R. D., J. V. Lizcano, T. H. S. Barros, F. S. Barbosa, D. P. V. Leal, L. da Costa Santos and, D. L. Martin. 2019. Effect of water stress on renewable energy from sugarcane biomass. Renew. Sustainable Energy Rev. 103: 399-407.

CONSECANA. 2006. Manual de instruções. Piracicaba.

Dalri, A. B. and R. L. Cruz. 2008. Produtividade da cana-de-açúcar fertirrigada com $\mathrm{N}$ e $\mathrm{K}$ via gotejamento subsuperficial. Eng. Agríc. 28: 516-524.

Dantas Neto, J., J. L. D. Figueredo, C. D. Farias, H. D. Azevedo and C. D. Azevedo, C. D. 2006. Resposta da cana-de-açúcar, primeira soca, a níveis de irrigação e adubação de cobertura. Rev. Bras. Eng. Agríc. Amb. 10: 283-288.

Dias, C. M. O., C. E. Corsato, V. M. Santos and A. F. S. Santos. 2012. Indicadores fitotécnicos, de produção e agroindustriais em cana de açúcar cultivada sob dois regimes hídricos. Rev. Caatinga. 25: 58-65.

Dinardo-Miranda, L. L., A. C. M. Vasconcelos, S. R. Vieira, J. V. Fracasso and C. R. Grego. 2007. Uso da geoestatística na avaliação da distribuição espacial de Mahanarva fimbriolata em cana-de-açúcar. Bragantia. 66: 449-455.

Farias, H. D. A., P. D. Fernandes, H. R. Gheyi and J. Dantas-Neto. 2009. Qualidade industrial de cana-de-açúcar sob irrigação e adubação com zinco, em Tabuleiro Costeiro paraibano. Rev. Bras. Eng. Agric. Amb. 13: 419-428.

Fernandes, A. C. 2003. Cálculos na Agroindústria Canavieira. Piracicaba: Sociedade dos Técnicos Açucareiros e Alcooleiros do Brasil.

Gonçalves, W. G., E. D. C. Severiano, F. G. Silva, K. A. D. Costa, W. D. S. Guimarães-Junnyor and G. B. Melo. 2014. Least limiting water range in assessing compaction in a Brazilian Cerrado latosol growing sugarcane. Rev. Bras. Ciênc. Solo. 38: 432-443.

Hossain, M. K., M. R. Karim, M. R. Chowdhury, M. A. Imam, M. Hosur, S. Jeelani, R. Farag. 2014. Comparative mechanical and thermal study of chemically treated and untreated single sugarcane fiber bundle. Ind. Crops Prod. 58: 78-90.

Júnior, S. D. O., J. R. de Andrade, C. M. dos Santos, J. A. C. Silva, K. P. Santos, J. V. Silva and L. Endres. 2019. Leaf thickness and gas exchange are indicators of drought stress tolerance of sugarcane. Emir. J. Food Agric. 31: 29-38.

Korndörfer, G. H., A. C. Ribeiro and L. A. B. Andrade. 1999. Cana-deaçúcar: sugestões de adubação para grandes culturas anuais ou perenes. In: A. C. Ribeiro, P. T. G. Guimarães, V. H. Alvarez, (Eds.), Recomendações Para o Uso de Corretivos e Fertilizantes em Minas Gerais - $5^{a}$ aproximação. Comissão de Fertilidade do Solo do Estado de Minas Gerais, Viçosa.

Lakshmanan, P. and N. Robinson. 2014. Stress physiology: Abiotic stresses. In: P. H. Moore, and F. C. Botha, (Eds.), Sugarcane: Physiology, Biochemistry, and Functional Biology. John Wiley and Sons, Inc., Chichester.

Li, Y. R. and L. T. Yang. 2015. Sugarcane agriculture and sugar industry in China. Sugar Tech. 17: 1-8.
Montenegro, S. and R. Ragab. 2012. Impact of possible climate and land use changes in the semi arid regions: A case study from North Eastern Brazil. J. Hydrol. 434-435: 55-68.

Neto, J. R., Z. M. Souza, O. T. Kölln, J. L. N. Carvalho, D. A. Ferreira, G. A. F. Castioni, L. C. Barbosa, S. G. Q. Castro, O. A. Braunbeck, A. L. Garside and H. C. J. Franco. 2018. The arrangement and spacing of sugarcane planting influence root distribution and crop yield. BioEnergy Res. 11: 291-304.

Oliveira, F. M., P. B. Aguilar, M. F. F. Teixeira, I. Aspiazú, F. P. Monção and A. P. S. Antunes, 2014. Características agrotecnólogicas de cana-de-açúcar em diferentes épocas de supressão de irrigação e níveis de adubação. Semina. 35: 1587-1606.

Otto, R., P. C. O. Trivelin, H. C. J. Franco, C. E. Faronia and A. C. Vitti. 2009. Root system distribution of sugar cane as related to nitrogen fertilization, evaluated by two methods: monolith and probes. Rev. Bras. Ciênc. Solo. 33: 601-611.

Parsaee, M., M. K. D. Kiani and K. Karimi. 2019. A review of biogas production from sugarcane vinasse. Biomass Bioenergy. 122: 117-125.

Pedro-Escher, J., C. A. Christofoletti, Y. Ansoar-Rodríguez and C. S. Fontanetti. 2016. Sugarcane vinasse, a residue of ethano industry: toxic, cytotoxic and genotoxic potential using the Allium cepa test. J. Environ. Prot. 7: 602-612.

Prado, R. M. and M. A. Pancelli. 2006. Nutrição em soqueira e a qualidade tecnológica da cana-de-açúcar. STAB: Açúcar, Álcool e Subprodutos. 25: 60-63.

Rhein, A. F., R. P. Pincelli, M. T. Arantes, W. J. Dellabiglia, O. T. Kölln and M. D. A. Silva. 2016. Technological quality and yield of sugarcane grown under nitrogen doses via subsurface drip fertigation. Rev. Bras. Eng. Agríc. Amb. 20: 209-214.

Santana, P. B., I. Aspiazú, E. L. da Costa, D. T. Pinheiro, M. F. F. Teixeira, J. B. R. da Silva and H. C. Santos Junior. 2017 Agronomical performance of sugarcane varieties in function of different irrigation depths in semi-arid conditions. J. Exp. Agric. Int. 17: 1-10

Santos, H. G. 2013. Sistema Brasileiro de Classificação de Solos. Embrapa, Brasília.

Silva, M. A., E. M. Jeronimo, A. D. C. Lucio. 2008. Perfilhamento e produtividade de cana-de-açúcar com diferentes alturas de corte e épocas de colheita. Pesq. Agropec. Bras. 43: 979-986.

Silva, M. D. A., M. T. Arantes, A. F. D. L. Rhein, G. J. Gava and O. T. Kolln. 2014. Potencial produtivo da cana-de-açúcar sob irrigação por gotejamento em função de variedades e ciclos. Rev. Bras. Eng. Agríc. Amb. 18: 241-249.

Silva, P. P., L. Soares, J. G. Costa, L. S. Viana, J. C. F. Andrade, E. R. Gonçalves, J. M. Santos, V. S. Barbosa, V. X. Nascimento, A. R. Todaro, A. Riffel, F. G. Sá, M. H. P. Barbosa, A. E. G. Sant'Ana and C. E. Ramaleho Neto. 2012. Path analysis for selection of drought tolerant sugarcane genotypes through physiological components. Ind. Crops Prod. 37: 11-19.

Souza, Z. M., A. C. S. Paixão, R. M. Prado and L. G. Cesarin. 2005 Níveis de palhada do canavial e qualidade do caldo. Cienc. Rur. 35: 1061-1068.

Stupiello, J. P. 1987. A cana-de-açúcar como matéria-prima. In: S. B. Paranhos, (Ed.), Cana-de-açúcar: Cultivo e Utilização. Fundação Cargill, Campinas.

Surendran, U., M. Jayakumar and S. Marimuthu. 2016. Low cost drip irrigation: impact on sugarcane yield, water and energy saving in semiarid tropical agro ecosystem in India. Sci. Total Environ. 573: $1430-1440$.

Surendran, U. and V. Murugappan. 2010. Pragmatic approaches to manage soil fertility in sustainable agriculture. J. Agron. 9: 57-69. 
Tasso Júnior, L. C., M. Omir Marques, H. F. D. Silva Neto, F. Camilotti, J. H. Bernardi and T. A. R. Nogueira. 2009. Variação genotípica no florescimento, isoporização e características tecnológicas em seis cultivares de cana-de-açúcar. Rev. Bio. Ciênc. Terra, 9: 12-18.

Uribe, R. A., G. J. D. C. Gava, J. C. Saad and O. T. Kölln. 2013. Ratoon sugarcane yield integrated drip-irrigation and nitrogen fertilization. Eng. Agríc. 33: 1124-1133.

USDA-United States Department of Agriculture. 2018. Sugar: World Markets and Trade. Available from: https://www.apps.fas.usda. gov/psdonline/circulars/sugar.pdf. [Last accessed on 2018 Jun 08].

Walter, A., M. V. Galdos, F. V. Scarpare and M. R. L. Leal, J. E. A. Seabra, M. P. Cunha, M. C. A. Picoli, C. O. F. Oliveira. 2014. Brazilian sugarcane ethanol: developments so far and challenges for the future. Wiley Interdiscipl. Reviews: Energy and Environ. 3: 70-92.

Zhao, D., B. Glaz and J. C. Comstock. 2013. Sugarcane leaf photosynthesis and growth characters during development of water-deficit stress. Crop Sci. 53: 1066-1075. 